\title{
CONTRIBUTION OF LEARNING ATTITUDE TO WRITING SKILLS EXPOSITION DISCOURSE OF CLASS XI STUDENTS SMK NEGERI 1 TANAH DATAR
}

\author{
Elvina A. Saibi ${ }^{1}$, Aimifrina ${ }^{2}$, Fitra Afrida Amna ${ }^{3}$ \\ ${ }^{1}$ Postgraduate Lecturer of Indonesian Language And Literature Education Bung Hatta \\ University, Padang \\ ${ }^{2}$ Postgraduate Lecturer of Indonesian Language And Literature Education Bung Hatta \\ University, Padang \\ ${ }^{3}$ Postgraduate Lecturer of Indonesian Language And Literature Education STIKES Syedza \\ Saintika, Padang \\ Email : elvinaasaibi@gmail.com
}

*Corresponding Author, Received: November 12, 2019, Revised: December 10, 2019, Accepted: December 21, 2019

\begin{abstract}
This study aims to determine the contribution of learning attitudes and learning motivation to the writing skills of exposition students of class XI SMK Negeri 1 Batipuh. This research is a type of cor-relational research. The population of all students of class XI of SMK Negeri 1 Batipuh totaling 187 people and a sample of 65 students. The instruments of this research were questionnaire and performance test. The results of the validity of the student learning attitude questionnaire were declared valid and the results of the reliability test were used reliably / reliable. The technique of analyzing research data uses the Kolmogorov-Smirnov test, multiple correlation test, $t$ test, F test, and the determinant coefficient formula. The results of this study are learning attitudes contribute to the writing skills of exposition discourse by $10.0 \%$. The conclusion of the study is the attitude of learning provides a significant positive contribution and relationship to the writing skills of exposition discourse.
\end{abstract}

Keywords : Learning, Attitudes, Writing Skills

\section{INTRODUCTION}

Indonesian language learning aims to make students skilled in communicating both verbally and in writing (Silaban, Ambarita, \& Hadi, 2018). Indonesian language learning, provides knowledge on how to use Indonesian language appropriately, creatively, and meaningfully(Fitra Afrida Amna, 2018). through learning Indonesian, students learn to behave and interact by using language. By learning Indonesian, 


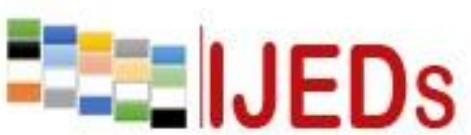

http://ijeds.ppj.unp.ac.id/index.php/IJEDS
International Journal of Educational Dynamics

Vol. 2 No. 1 (pp. 24-29) Desember 2019

p_ISSN 2655-4852

e_ISSN 2655-5093

students are expected to be able to use language as a means of acquiring and conveying knowledge (Ariningsih, Sumarwati, \& Saddhono, 2012).

Writing skills are one of the basic competencies of Indonesian subjects contained in the Education Unit Level Curriculum (KTSP) in Vocational High Schools (SMK). Basic competencies related to writing skills in the SMK curriculum, one of which is found in class XI, namely "writing narrative discourse, description, exposition, and argumentation". This basic competency is described in several indicators consisting of: (1) Writing an event in the form of narrative chronologically, (2) describing pictures, charts, tables, graphs, diagrams, matrices as much as 150-200 words, (3) making exposition of an event, and (4) construct an argument with the aim of convincing the reader of an event.

Ability is a potential knowledge of students and academic performance (Castejon, Gilar, Minano, \& Veas, 2016).Student behavior in the classroom has become a measurable proxy for student learning. Such behavior can be measured directly, immediately, and continuously through observation (Castejon et al., 2016).

The low skill of students in writing exposition essays is assumed to be influenced by several factors, including attitudes toward learning to write exposition essays. A person's attitude towards something will be shown through behavior. Student learning attitudes in learning will be seen based on student behavior in learning and responses to learning. Improved student learning outcomes play an important role in changing teacher attitudes and beliefs about educational strategies (Septhin, Mulawarman, \& Suhatmady, 2018). Students who are positive towards and open to accept learning will give encouragement to students to achieve success (Castejon et al., 2016). A positive attitude will form a good relationship between students and educators, thus facilitating the learning process otherwise a negative attitude towards learning will have an adverse effect on student learning outcomes. This is why education does not meet the educational objectives of East Asia today (Galton, Lai, \& Chan, 2018). Based on (Stewart et al., 2019) the causes of data that might indicate students are not motivated to write because of low self-confidence, lack of control over writing assignments, insufficient amount of time to expand writing, lack of emphasis on organizers, limited peer collaboration, and inadequate relevance to real life (Silaban et 


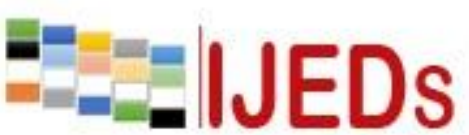

http://ijeds.ppj.unp.ac.id/index.php/IJEDS
International Journal of Educational Dynamics

Vol. 2 No. 1 (pp. 24-29) Desember 2019

p_ISSN 2655-4852

e_ISSN 2655-5093

al., 2018). The faculty reports a lack of student motivation in writing assignments that hinders writing achievement (Grünke, 2019). Country data shows a decrease in writing value on the targeted site(Castejon et al., 2016).

Student learning attitudes contribute to student success in writing exposition essays. Students who are diligent, confident, and concerned about learning to write exposition essays will try to write exposition essays well (Woodcock, Hitches, \& Jones, 2019). Students will try to achieve their goals with positive actions. Thus, the results achieved in writing exposition essays will be better (Salikin, Bin-Tahir, Kusumaningputri, \& Yuliandari, 2017).

Based on the description above, it is clear that attitudes and learning motivation are factors that are assumed to be able to make a positive contribution to thewriting skills of students' exposition writing. Student learning attitude will determine the actions that students will take in learning activities. A positive attitude will provide high learning motivation to students, and foster a desire to achieve success (Harfitt, Fung, \& Liang, 2018). Based on the problems that have been raised, then the focus of this study is "The Contribution of Attitudes and Learning Motivation to the Writing Skill of Exposition of Class XI Students of SMK Negeri 1 Batipuh".

\section{METHOD}

This study uses quantitative methods with cor-relational research types to see the contribution of learning attitudes and learning motivation to the writing skills of exposition students of class XI of SMK Negeri 1 Batipuh for Academic Year 2015 / 2016. The population in this study is class XI of SMK Negeri 1 Batipuh, totaling 182 people which is spread into 8 classes. Sampling with simple random sampling technique from a population of 187 people with an estimated error rate of $10 \%$ of the total sample of 65 people. Data collection was done by testing the validity of the learning attitude questionnaire and student learning motivation. The data analysis technique of this research will be processed using correlation and regression techniques with the help of SPSS version 20.

\section{RESULTS AND DISCUSSION}

The results of the validity of the student learning attitude questionnaire obtained 30 items that were declared valid from 28 items tested. The results of the 
http://ijeds.ppj.unp.ac.id/index.php/IJEDS

reliability test are obtained $r_{11}$ amounted to 0.926 , it was concluded that the research instrument used was reliable / reliable. The results of this study are learning attitudes contribute to the writing skills of exposition discourse by $10.0 \%$. The conclusion of the study is the attitude of learning provides a significant positive contribution and relationship to the writing skills of exposition discourse.

The hypothesis proposed in this study is that the attitude of learning $\left(\mathrm{X}_{1}\right)$ is significantly related to the writing skills of exposition discourse (Y) SMK Negeri 1 Batipuh. Hypothesis testing is carried out as follows.

$\mathrm{H}_{1}$ : There was a significant contribution of learning attitudes towards the writing skills of exposition discourse of grade XI students of SMK Negeri 1 Batipuh.

$\mathrm{H}_{0}$ : There was no significant contribution, the attitude of learning towards the writing skills of exposition discourse of class XI students of SMK Negeri 1 Batipuh.

In proving the above hypothesis, a hypothesis test is performed using the Pearson product moment correlation test formula. After knowing the relationship between learning attitudes with exposition discourse writing skills, sought the contribution of learning attitudes towards exposition discourse writing skills. The results of the calculation of the first hypothesis test are as follows.

\section{Hypothesis Testing}

\begin{tabular}{|l|l|l|l|l|}
\hline Correlation between Variables & $\begin{array}{l}\text { Correlation } \\
\text { coefficient( }\end{array}$ & $\begin{array}{l}\text { Coefficis } \\
\text { Determination }\end{array}$ & $\mathbf{t}_{\text {count }}$ & $\mathbf{t}_{\text {table }}$ \\
\cline { 4 - 6 } & & & $\mathbf{a = 0 , 0 5}$ \\
\hline $\begin{array}{l}\text { Reading habit (X1) on the ability } \\
\text { to write exposition text (Y) }\end{array}$ & 0,316 & $0,10 \%$ & 7,004 & 1,67 \\
\hline
\end{tabular}

Based on the above table, it can be seen that the variable of learning attitudes $\left(\mathrm{X}_{1}\right)$ contributes to the variable of exposition writing skill discourse $(\mathrm{Y})$ of $0.10 \%$. This shows that the writing skill of exposition discourse (Y) contributes $0.10 \%$ by learning attitude $\left(\mathrm{X}_{1}\right)$, while the rest is influenced by other factors. Thus, the higher the attitude of learning, the higher the exposition writing skill (Y) of class XI students of SMK Negeri 1 Batipuh.

In testing the significance of the relationship of learning attitudes $\left(\mathrm{X}_{1}\right)$ to the writing skills of exposition discourse $(Y)$, a significance test was performed with t test. 


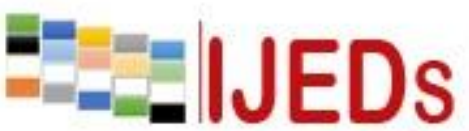

http://ijeds.ppj.unp.ac.id/index.php/IJEDS
International Journal of Educational Dynamics

Vol. 2 No. 1 (pp. 24-29) Desember 2019

p_ISSN 2655-4852

e_ISSN 2655-5093

After that, compare the value $t_{\text {count }}$ with $t_{\text {table. }}$. The testing principle is if $t_{\text {count }} \geq t_{\text {tablethen it }}$ is significant, if $\mathrm{t}_{\text {count }} \leq \mathrm{t}_{\mathrm{tablel}}$, it is not significant. Based on the significance test using the $t$ test obtained values $t_{\text {count }}$ of 7,004 meanwhile $t_{\text {tablewith }}$ an error rate $\alpha=0,05$ and $\mathrm{db}=$ $n-2=65-2=63$ of 1,67 . thus $t_{\text {count }}>t_{\text {table }}$ or7,004 $>1,67$. Thus, $H_{0}$ is rejected and $H_{1}$ is accepted, meaning the first hypothesis which reads the attitude of learning significantly contributes to the writing skills of exposition discourse of class XI students of SMK Negeri 1 Batipuh.

Furthermore, based on the linearity test of the regression model that has been done in the requirements analysis of the data pair of learning attitudes and writing exposition discourse skills (b) of 42,933 and constants (a) 0,286. Thus, the relationship of learning attitudes to exposition writing writing skills can be expressed by the regression equation $\hat{Y}=0,286+42,933 \mathrm{X}_{1}$. This shows that if there is no reading habit or $\mathrm{X}_{1}=0$,then the writing skill of exposition discourse has been around 0.286. The regression equation can be used for prediction, that is if the learning attitude is improved by one value, the exposition writing skill of discourse (Y) increases by 42,933. Therefore, if the students want to improve the writing skill of exposition discourse, their learning attitude must be improved.

\section{CONCLUSION}

. Based on the description of the data, it can be concluded that the ability to write exposition text is largely determined by the attitude of learning. The attitude of learning as a whole indicator is categorized as good, it means that the indicator really determines the ability to write discourse of students' exposition to increase well because it is influenced by the variable of learning attitudes. Thus, learning attitudes can be linked as determinants of the success of writing exposition discourse abilities.

\section{REFERENCES}

Ariningsih, N., Sumarwati, S., \& Saddhono, K. (2012). Analisis Kesalahan Berbahasa Indonesia Dalam Karangan Eksposisi Siswa Sekolah Menengah Atas. Jurnal Penelitian Bahasa, Sastra Indonesia, Dan Pengajarannya, 1(1), 130-141.

Castejon, J. L., Gilar, R., Minano, P., \& Veas, A. (2016). Identifying and establishing the attitudes and motivations of low academic performance in underachieving students. European Journal of Education and Psychology. https://doi.org/10.1016/j.ejeps.2016.04.001

Fitra Afrida Amna. (2018). Kontribusi Kebiasaan Membaca dan Motivasi Belajar 


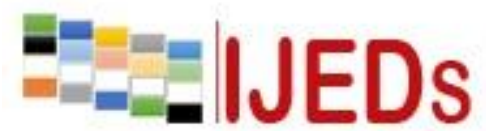

http://ijeds.ppj.unp.ac.id/index.php/IJEDS
International Journal of Educational Dynamics

Vol. 2 No. 1 (pp. 24-29) Desember 2019

p_ISSN 2655-4852

e_ISSN 2655-5093

terhadap Kemampuan Menulis Teks Ekposisi Siswa Kelas X SMA Negeri 2 Padang. Menara Ilmu, 12(6).

Galton, M., Lai, K. C., \& Chan, K. W. (2018). Implementing small class teaching in East Asia: Problems and possibilities. International Journal of Educational Research, (October), 0-1. https://doi.org/10.1016/j.ijer.2018.10.004

Grünke, M. (2019). The Effects of a Motivational Intervention on Improving the Writing Productivity of Students with Learning Disabilities. International Education Studies, 12(3), 36. Ariningsih, N., Sumarwati, S., \& Saddhono, K. (2012). Analisis Kesalahan Berbahasa Indonesia Dalam Karangan Eksposisi Siswa Sekolah Menengah Atas. Jurnal Penelitian Bahasa, Sastra Indonesia, Dan Pengajarannya, 1(1), 130-141.

Castejon, J. L., Gilar, R., Minano, P., \& Veas, A. (2016). Identifying and establishing the attitudes and motivations of low academic performance in underachieving students. European Journal of Education and Psychology. https://doi.org/10.1016/j.ejeps.2016.04.001

Fitra Afrida Amna. (2018). Kontribusi Kebiasaan Membaca dan Motivasi Belajar terhadap Kemampuan Menulis Teks Ekposisi Siswa Kelas X SMA Negeri 2 Padang. Menara Ilmu, 12(6).

Galton, M., Lai, K. C., \& Chan, K. W. (2018). Implementing small class teaching in East Asia: Problems and possibilities. International Journal of Educational Research, (October), 0-1. https://doi.org/10.1016/j.ijer.2018.10.004

Grünke, M. (2019). The Effects of a Motivational Intervention on Improving the Writing Productivity of Students with Learning Disabilities. International Education Studies, 12(3), 36. https://doi.org/10.5539/ies.v12n3p36

Harfitt, G., Fung, D., \& Liang, T. (2018). Promoting good practice in small classes: Lessons learnt from small class teaching professional development programmes in Hong Kong. International Journal of Educational Research, (August), 0-1. https://doi.org/10.1016/j.ijer.2018.10.005

Salikin, H., Bin-Tahir, S. Z., Kusumaningputri, R., \& Yuliandari, D. P. (2017). The Indonesian EFL Learners' Motivation in Reading. English Language Teaching, 10(5), 81. https://doi.org/10.5539/elt.v10n5p81

Septhin, K., Mulawarman, W. G., \& Suhatmady, B. (2018). MENULIS TEKS EKPOSISI SISWA KELAS XI SMK NEGERI 9 SAMARINDA. 1(2), 89-100.

Silaban, W., Ambarita, B., \& Hadi, U. (2018). The Development and Implementation of Learning Material on Exposition Text to Improve Students' Achievement on Bahasa Indonesia. International Education Studies, 11(11), 53. https://doi.org/10.5539/ies.v11n11p53

Stewart, G., Webster, C. A., Stodden, D. F., Brian, A., Egan, C. A., \& Weaver, R. G. (2019). The association of children's participation in school physical activity opportunities with classroom conduct. International Journal of Educational Research, 97(June), 22-28. https://doi.org/10.1016/j.ijer.2019.06.008

Woodcock, S., Hitches, E., \& Jones, G. (2019). It's not you, it's me: Teachers' selfefficacy and attributional beliefs towards students with specific learning difficulties. International Journal of Educational Research, 97(July), 107-118. https://doi.org/10.1016/j.ijer.2019.07.007 